\title{
Student's Digital Literacy Based on Students' Interest in Digital Technology, Internet Costs, Gender, and Learning Outcomes
}

\author{
https://doi.org/10.3991/ijet.v17i03.27151 \\ Wasis Wuyung Wisnu Brata( $\left.{ }^{\bowtie}\right)$, Rahma Yanti Padang, Cicik Suriani, Eko Prasetya, \\ Nanda Pratiwi \\ Universitas Negeri Medan, Medan, Indonesia \\ wasisbrata@unimed.ac.id
}

\begin{abstract}
This study aims to analyze students' digital literacy in the context of learning biology material on the digestive system and identify students' digital literacy in terms of interest in digital technology, internet costs, gender, and learning outcomes. The research was conducted at the one private high school in Medan, Indonesia. The instrument used is a questionnaire and a list of student grades from the teacher. The results showed that students interested in digital technology had a significantly higher digital literacy score than students who had less interest in digital technology. There was no significant difference in digital literacy between groups of students with internet fees < US\$ 14 per month and students with internet fees of US\$ 14 per month, and between groups of male and female students. The results of the analysis also found a positive correlation between learning outcomes and digital literacy.
\end{abstract}

Keywords—digital literacy, technology interest, internet costs, learning outcomes

\section{Introduction}

The presence of opportunities and threats in using digital technology presents a particular challenge to the world of education to literacy the younger generation in using and utilizing digital space [1]. Digital literacy is the most effective step in preparing individuals to adapt and compete in the era of digital transformation. Digital literacy will guide users to use digital technology wisely, intelligently, and appropriately to have a critical mindset in receiving and processing information and digital content [2]. On the other hand, the emergence of the Covid-19 outbreak requires learning from home under government instructions. The Ministry of Education and Culture provides and recommends various digital learning portals to support online distance learning activities. This condition requires the education unit to adapt to digital technology so that learning can continue during the pandemic [3].

The Ministry of Education and Culture defines digital literacy as knowledge and skills to use digital media, communication tools, or network access in finding, evalu- 
ating, using, creating, and utilizing information in a healthy, wise, intelligent, careful, precise, and obey the law to foster communication and interaction in daily life [4]. According to UNESCO (2018), digital literacy is the ability to access, manage, understand, integrate, communicate, evaluate, and create information safely and appropriately through digital technology to get decent work, employment, and entrepreneurship. Digital literacy includes various competencies, namely computer literacy, ICT literacy, information literacy, and media literacy [5]. While UNESCO uses the term digital literacy, the European Commission (2019) provides the term digital competence, which is a competence that involves the confidence, critical and responsible use of, and engagement with digital technologies for learning, work, and participation in society. Digital competencies include information and data literacy, communication and collaboration, media literacy, digital content creation (including programming), security (including digital wellbeing and cybersecurity), intellectual property rights, problem-solving, and critical thinking [6].

As a government agency that handles the field of education in Indonesia, the Ministry of Education and Culture suggests eight elements of digital literacy developed by Belshaw [7] as a reference in running the national digital literacy program. This study adopts the eight elements of digital literacy, namely elements of culture, cognitive, constructive, communicative, confident, creative, critical, and civic. Cultural elements discuss students' understanding in approaching various digital environments with different situations and contexts of use. The cognitive element discusses developing thinking habits that impact the development of students' insights using digital technology. The constructive element discusses students' knowledge and skills in using digital technology to create a work by considering the creative commons license. The communicative element discusses students' awareness of different interaction patterns in each different community. The confident element discusses students' confidence in utilizing digital resources. Creative elements discuss students' skills in creating digital works in new ways to add value from specific contexts. Critical elements discuss students' understanding and skills in assessing content widely available on social networks. The civic element discusses students' understanding of their rights and obligations when participating in the digital space [8].

As an educational institution, schools have a mission to prepare students to adapt to technological developments. The Deputy Principal revealed several strategies that were considered appropriate to realize this mission, including designing policies related to the implementation of digital technology in the school environment, increasing teacher understanding and skills on digital technology, and completing supporting digital facilities and infrastructure. To improve teachers' understanding and skills towards digital technology, the school collaborates with several expert institutions, namely Medan State University, North Sumatra University, and Polytechnic Port Dickson Malaysia, to conduct consultations, seminars, and training for students to develop their ability to integrate digital technology in learning. According to the Deputy Principal, this collaboration provides knowledge to teachers on how to access digital space, access information and educational content, online teaching strategies, eradicate hoaxes and harmful content, and etiquette and security using digital spaces. The school also provides facilities and infrastructure that support the continuity of the 
digitization program by providing a computer lab complete with $\mathrm{Wi}-\mathrm{Fi}$ access that can be used by teachers and students when learning requires computer applications. The school also agreed to use e-modules from the Ministry of Education and Culture as additional reading material.

Based on the information from the biology teacher, the skills gained from seminars and training have been applied intensively in learning. Teachers apply technology in learning by using learning media to explain the material, teaching students how to access e-modules from the website, teaching polite language procedures when interacting on social networks, and guiding students to collaborate digitally in doing assignments. The teacher already knows that using web-enhanced learning can promote students' learning outcomes [9]. So, they were asking students to use various learning resources when working on project assignments and daily assignments.

With this background, this study aims to answer research questions: How is student digital literacy in terms of students' interest in digital technology, internet costs, and gender? Are there significant differences between these groups of students? Moreover, how does it relate to learning outcomes?

\section{Method}

The research was conducted at the Privat High School in Medan, Indonesia, from January to April 2021. A sample of 61 students (21 male, 40 female) was taken using a purposive sampling technique where the primary reference of the sample criteria was based on the availability of networks and digital access tools in the form of smartphones and laptops/computers. The pre-study results show that only two classes meet these criteria. The sample was divided into two groups based on the research variables. In the interest variable, students are grouped into groups of students interested in digital technology and students who are not interested in digital technology. On the internet cost variable, students were grouped into groups of students with internet fees < US\$ 14 per month and students with internet costs US\$ 14 per month. On the gender variable, students were grouped into groups of male and female students.

Analysis of student digital literacy is assessed from the eight elements of digital literacy suggested by [7], namely cultural, cognitive, constructive, communicative, confident, creative, critical, and civic. The digital literacy measurement instrument uses 31 statements in a closed questionnaire and ten questions in an open questionnaire. The scoring rules for the closed questionnaire use a Likert scale consisting of 5 options: strongly agree (score 5 for positive statements, score 1 for negative statements), agree (score 4 for positive statements, score 2 for negative statements), disagree (score 4 for negative statements), 3), disagree (score 2 for positive statements, score 4 for negative statements), and strongly disagree (score 1 for positive statements, score 5 for negative statements). The instrument used has passed the validity and reliability tests by experts and field trials with 30 respondents. Data were analyzed using SPSS 25 software with descriptive analysis techniques, qualitative analysis, independent sample t-test, and bivariate correlation test specifically for learning 
outcomes. The data from the closed questionnaire have passed the normality and homogeneity tests as a condition for the independent sample t-test.

\section{Results}

\subsection{Students' digital literacy in terms of interest in digital technology}

The level of digital literacy of students interested in digital technology (n1) in the elemental realm is in the high category, with an average score of 3.90. Meanwhile, students who are less interested in learning digital technology (n2) have a digital literacy score of 3.40, which is in the medium category. Descriptions of digital literacy of the two groups of students on each element of digital literacy can be seen in Table 1 .

Table 1. Students' digital literacy based on their interest in digital technology

\begin{tabular}{|l|c|c|c|c|c|c|c|c|}
\hline \multirow{2}{*}{ Digital literacy elements } & \multicolumn{3}{|c|}{ Interested in digital technology } & \multicolumn{4}{c|}{ Less interested } \\
\cline { 2 - 10 } & $\boldsymbol{n}$ & Mean & Value & Category & $\boldsymbol{n}$ & Mean & Value & Category \\
\hline Culture & 31 & 16,77 & 4,19 & High & 30 & 15,43 & 3,86 & High \\
\hline Cognitive & 31 & 12,65 & 4,22 & Very high & 30 & 11,77 & 3,92 & High \\
\hline Constructive & 31 & 15,36 & 3,84 & High & 30 & 13,50 & 3,38 & Moderate \\
\hline Communicative & 31 & 32,67 & 4,10 & High & 30 & 28,40 & 3,55 & High \\
\hline Confident & 31 & 11,52 & 3,84 & High & 30 & 9,57 & 3,19 & Moderate \\
\hline Critical & 31 & 12,61 & 3,20 & Moderate & 30 & 9,77 & 2,44 & Low \\
\hline Civic & 31 & 19,90 & 3,98 & High & 30 & 16,90 & 3,38 & Moderate \\
\hline Creative & 31 & 11,42 & 3,80 & High & 30 & 10,33 & 3,44 & High \\
\hline Average & & 16.61 & 3,90 & High & & 14.46 & 3,40 & Moderate \\
\hline Total & & 132,90 & & & & 115,67 & & \\
\hline
\end{tabular}

Independent sample t-test showed that the mean digital literacy score n1 (132.9 $\pm 7.9)$ was significantly higher than the mean digital literacy score n2 (115.8 \pm 6.0$)$ with $(\mathrm{t}=9.62, \mathrm{p}=.001)$ at the $95 \%$ confidence level and the average difference is 17,237 . The comparison of the average scores obtained by students $n 1$ and $n 2$ can be seen in Figure 1. 


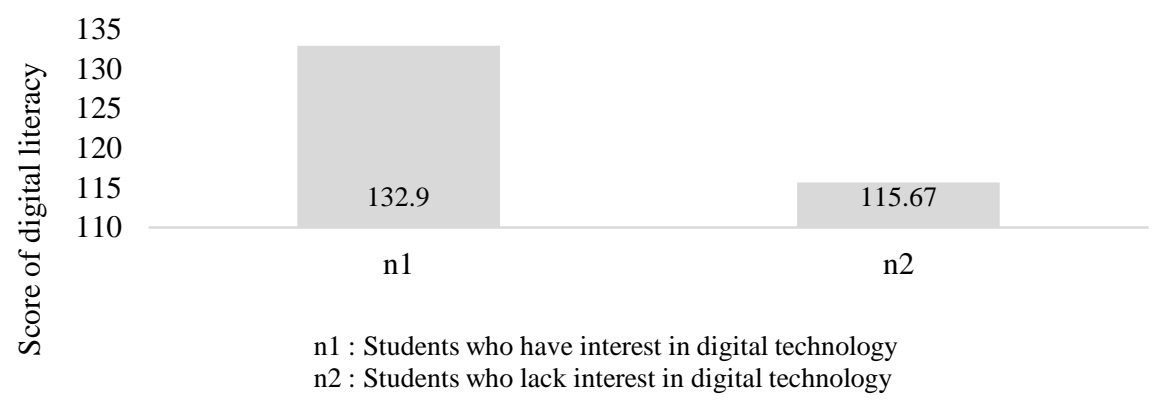

Fig. 1. Comparison of the digital literacy scores of students who have interest and are less interested in digital technology

\subsection{Digital literacy of students in terms of internet costs per month}

Students are divided into two groups, namely students with quota/wifi fees $\geq$ of US\$ 14 and students with quota/wifi fees < US\$14. The digital literacy level of students with quota/wifi fees $\geq$ of US\$ 14 has a digital literacy score of 3.70 or is in the high category, while the digital literacy score of students with quota/wifi < US\$ 14 is 3.63 or is in the high category. The description of digital literacy of the two groups of students on each element of digital literacy can be seen in Table 2.

Table 2. Students' digital literacy in terms of internet costs

\begin{tabular}{|l|c|c|c|c|c|c|c|c|}
\hline \multirow{2}{*}{ Elements of Digital Literacy } & \multicolumn{3}{|c|}{ Internet fees $\mathbf{U S \$}$ 14/month } & \multicolumn{3}{|c|}{ Internet fees < US\$ 14/month } \\
\cline { 2 - 10 } & $\boldsymbol{n}$ & Mean & Value & Category & $\boldsymbol{n}$ & Mean & Value & Category \\
\hline Cultural & 27 & 16,33 & 4,08 & High & 34 & 15,94 & 3,99 & High \\
\hline Cognitive & 27 & 12,04 & 4,01 & High & 34 & 12,35 & 4,12 & High \\
\hline Constructive & 27 & 14,67 & 3,67 & High & 34 & 14,27 & 3,56 & High \\
\hline Communicative & 27 & 31,07 & 3,88 & High & 34 & 30,18 & 3,77 & High \\
\hline Confident & 27 & 10,56 & 3,52 & High & 34 & 10,56 & 3,52 & High \\
\hline Critical & 27 & 11,48 & 2,87 & Moderate & 34 & 11,00 & 2,75 & Moderate \\
\hline Civic & 27 & 18,52 & 3,70 & High & 34 & 18,35 & 3,67 & High \\
\hline Creative & 27 & 11,11 & 3,70 & High & 34 & 10,71 & 3,57 & High \\
\hline Rata-rata & & 15.72 & 3,70 & High & & 15.42 & 3,63 & Moderate \\
\hline Total & & 125,78 & & & & 123,35 & & \\
\hline
\end{tabular}

Independent sample t-test shows that the average digital literacy score of students with quota/wifi costs $\geq$ US\$ $14 /$ month $(125,78 \pm 13,46)$ not significantly different from students with quota/wifi costs <US\$ 14/month $(123,35 \pm 8,95)$ with $(\mathrm{t}=.842, \mathrm{p}$ $=.403$ ). The comparison of the average scores obtained by students in the two-class groups can be seen in Figure 2. 


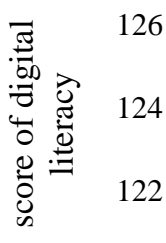

120

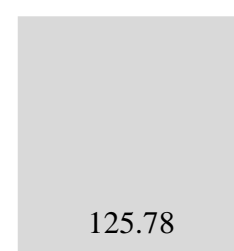

$\mathrm{n} 1$
123.35

$\mathrm{n} 2$

$\mathrm{n} 1:$ students with internet cost $\geq$ US\$ 14

n2 : students with internet cost $<$ US\$ 14

Fig. 2. Comparison of the Digital Literacy for the Group of Students with internet cost $\geq$ US\$ 14 and < US\$ 14

\subsection{Digital literacy of students in terms of gender}

Students are divided into two groups, namely male and female students. The digital literacy level of male students has a digital literacy score of 3.71 or is in the high category, while the digital literacy score of female students is 3.64 or is in the high category. Descriptions of digital literacy of the two groups of students on each element of digital literacy can be seen in Table 3.

Table 3. Digital literacy of students in terms of gender

\begin{tabular}{|l|c|c|c|c|c|c|c|c|}
\hline \multirow{2}{*}{ Element of Digital Literacy } & \multicolumn{3}{|c|}{ Male students } & \multicolumn{2}{c|}{ Female Students } \\
\cline { 2 - 9 } & $\boldsymbol{n}$ & Mean & Value & Category & $\boldsymbol{n}$ & Mean & Value & Category \\
\hline Cultural & 21 & 15,95 & 3,99 & High & 40 & 16,20 & 4,05 & High \\
\hline Cognitive & 21 & 12,43 & 4,14 & High & 40 & 12,10 & 4,03 & High \\
\hline Constructive & 21 & 15,14 & 3,79 & High & 40 & 14,08 & 3,52 & High \\
\hline Communicative & 21 & 30,40 & 3,80 & High & 40 & 30,65 & 3,83 & High \\
\hline Confident & 21 & 10,76 & 3,59 & High & 40 & 10,45 & 3,48 & High \\
\hline Critical & 21 & 11,10 & 2,77 & Moderate & 40 & 11,23 & 2,82 & Moderate \\
\hline Civic & 21 & 19,10 & 3,82 & High & 40 & 18,08 & 3,62 & High \\
\hline Creative & 21 & 11,14 & 3,71 & High & 40 & 10,75 & 3,58 & High \\
\hline Mean & & 15.27 & 3,71 & High & & 15.44 & 3,63 & High \\
\hline Total & & 126,05 & & & & 123,58 & & \\
\hline
\end{tabular}

Independent sample t-test shows that the average digital literacy score of male students $(126,05 \pm 13,14)$ not significantly different from female students $(123,58$ $\pm 10,01)$ with $\mathrm{t}=.76, \mathrm{p}=.46$ at the $95 \%$ confidence level with an average difference of 2.473. The comparison of the average scores obtained by students in the two-class groups can be seen in Figure 3. 


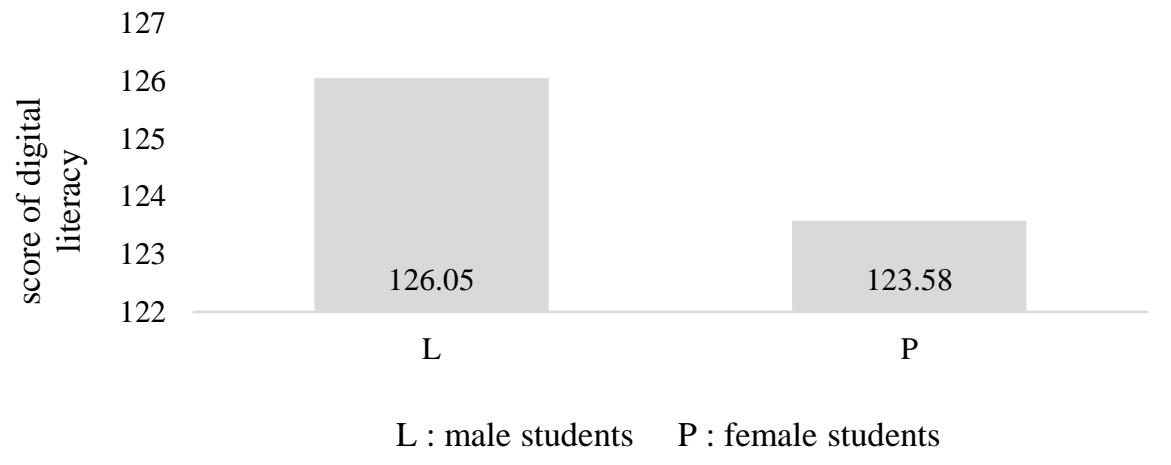

Fig. 3. Comparison of the average digital literacy scores of male and female students

Although there was no significant difference in digital literacy between male and female students on the independent sample t-test for all elements, examination of each element revealed that the digital literacy scores of male students $(15,14 \pm 2,27)$ were significantly higher than female students' digital literacy scores $(14,08 \pm 1,64)$ when viewed from the constructive element $(\mathrm{t}=2.11, \mathrm{p}=.039)$. After examining the constructive elements, it is known that the cause of this significant difference lies in the indicators of building digital works in the form of simple videos. As many as $80 \%$ of the male students can make simple learning videos about digestive system materials, while about $60.2 \%$ of female students can do it.

\section{Discussion}

\subsection{Digital literacy on students' interest in digital technology, internet costs, gender}

This study found that the digital literacy score of students who had an interest in digital technology was significantly higher than the group of students who had no interest in digital technology. In this case, interest acts as a motivation that affects students psychologically to pay attention, learn, and engage with things related to digital technology from time to time [12]. On the other hand, the best way to be digitally literate is to blend in and engage with various activities in different digital environments [8]. There is a significant difference in digital literacy because students are interested in learning things related to digital technology. It encourages them to learn how specific digital tools work, which leads to the development of their skills in utilizing digital technology tools creatively. In addition, the existence of extrinsic motivation that creates a competitive spirit among $\mathrm{n} 1$ students encourages them to hone their skills further using digital tools.

Students' respons related to the culture element indicator illustrates that both groups of students have known and applied some basic etiquette and culture of using WhatsApp as an online learning room as explained by the following students: 
"... if you want to ask something that is not clear to the teacher, you have to go through the class president or secretary, except for personal things. Use good and formal language, not abbreviated. Use greetings and acknowledgments at the end of the message-no spamming in groups. Do not send messages before check-in hours and when it is 5 pm. teaches us to pay attention to punctuation... ". [student AH].

A significant difference in students' response is seen in one item of culture elements, which shows that most respondents of $n 1$ can keep concentrating while learning online and are not distracted by entertainment content from their smartphone applications, while in $\mathrm{n} 2$, only $22.6 \%$ of students do it.

The review conducted on students' responses on cognitive elements illustrates that both groups of students already know how to operate Google, YouTube, and the government's e-modules to use them as learning resources to broaden their horizons about the digestive system. The role of biology teachers in developing cognitive elements is carried out by requiring students to use applications such as Google and YouTube as learning resources to obtain information that can broaden students' horizons about the digestive system. To ensure that students use both applications, the teacher gives a paper assignment requiring students to search for information about the digestive system using Google and include a YouTube link on the student's PowerPoint slide. The biology teacher also introduced the Kemendikbud e-module and taught students directly how to access and search for biology modules on the page. A significant difference is seen in students' responses related to cognitive elements, which shows that $90.3 \%$ of n1 often use YouTube as a learning resource, while in $\mathrm{n} 2$, only $51.6 \%$ of students do so.

The constructive element indicator shows that both students have created digital content such as PowerPoints and simple videos. However, both groups of students still ignore Creative Commons and do not even know about it. A significant difference can be seen in one item of the constructive element, which shows that 96.8\% of $\mathrm{n} 1$ have made simple PowerPoint slides containing text, pictures, and designs from the default PowerPoint template, while in $\mathrm{n} 2$, only $64.5 \%$ can do it. This data is due to the things that motivate $\mathrm{n} 1$ students to be interested in studying PowerPoint in-depth, as expressed by the following students:

“... PowerPoint to create nice and attractive slides ... " [student BN].

“... PowerPoint to make great presentations and get high marks... " [student KJ].

The increase in digital interaction during the pandemic has shaped a new social environment with distinctive values and rules of communication behavior [13]. Students' understanding of this new type of communication becomes an important part and an indicator of digitally literate students. The communicative element indicator illustrates that both students already know how to operate WhatsApp as a communication medium used in online learning and how to interact ethically in a digital classroom. This understanding of students was obtained from biology teachers, parents, and classmates who taught the ethics of communicating in digital spaces, especially in online classrooms. Some of the students' expressions that show the role of parents, biology teachers, and classmates in developing communicative elements are as follows: 
"Speak politely if you want to send a message to the teacher, such as greeting first, then conveying the message briefly and clearly, then ending with a greeting. send a message must also see the time ". [parents].

"1) don't spam the group, 2) respect different opinions during group discussions, 3) teach how to send a message if a friend wants to send a private message to the teacher because I'm the class secretary". [classmate].

"Use good and formal language, not abbreviated. Use greetings and acknowledgments at the end of the message. No spam in the group ... pay attention to punctuation ... ". [biology teacher].

The confident element indicator illustrates that the $\mathrm{n} 1$ student group is more confident in using digital resources than the $\mathrm{n} 2$ student group. The findings show that $74.2 \%$ of $\mathrm{n} 1$ are confident in trying various features of an application or software, while in $\mathrm{n} 2$, only $54.9 \%$ of students are confident in doing so. To become digitally literate, one must be confident in trying out various features that they have never used before [8]. However, not everyone dares to do it. For those who are confident and dare to take a trial and error approach in learning digital technology, the possibility of digital literacy skills is better than those who do not. In addition to being confident in trying out application or software features, $\mathrm{n} 1$ is also more confident in using social media for discussion and information exchange. The results showed that $64.5 \%$ of $n 1$ stated that they were confident and dared to comment on an Instagram post that provided false information about the digestive system, while in $\mathrm{n} 2$, only $10 \%$ dared to do so.

The critical element indicator illustrates that the two groups of students do not pay attention to the credibility of the website and the content they will use as learning resources. Only $6.5 \%$ of students from $\mathrm{n} 1$ checked the website's credibility and content, while in n2, no students did. Almost all students use personal blogs, Blogspot, and WordPress whose identity and background are not clear. This happens because the teacher never teaches it. Further findings show that $77.5 \%$ of students from $\mathrm{n} 1$ check the correctness of information they get from Google before distributing it to the class group, while in $\mathrm{n} 2$, only $29 \%$ of students do it. Due to a lack of knowledge, people tend to trust any information they get from the internet [14][15]. The low awareness of group $\mathrm{n} 2$ in checking information is due to the assumption that any information they get from Google is correct and lacks knowledge in this regard, as expressed by the following students:

"in my opinion, what google is telling you is usually correct" [student AL].

"if there are special ways to find out whether the information from google is correct or not, I don't know because I have never been told how. Usually what I get from Google I'm sure the information is correct and trustworthy " [student AT].

The civic element illustrates that the $\mathrm{n} 1$ student group understands their digital rights and obligations better than the $\mathrm{n} 2$ student group. The $\mathrm{n} 1$ student group understands that they have digital rights in the form of privacy rights, expression, collaboration, and creativity in digital. In addition to better understanding their digital rights, the $\mathrm{n} 1$ group of students also better understand their digital obligations. When teachers are given the right to express themselves in a digital classroom, students use appropriate and formal language. When granted the right to extract any content from 
the internet, students give credit to the work owner according to the applicable license. When given the right to disseminate information in class groups, students can be held accountable for that information.

A review of the creative elements illustrates that the $n 1$ student group is more creative in utilizing digital tools than the $\mathrm{n} 2$ student group. Some of the statements of N1 students who use digital tools creatively are as follows:

“.... PowerPoint is not only for presentations but also for designs such as posters, when there are activities that require this skill I can already. (,) Filmora for simple video editing and Adobe Premiere for those who ordered videos for me ... " [student $A W]$.

“... video editing using in shoot because I'm a content creator promoting my music and rap skills" [student $A H$ ].

“... I really like designing mindmaps with an aesthetic look with the help of Ms. Words... " [student TZ].

There is a significant difference in digital literacy because N1 students are more interested in learning technology-related things, thus encouraging them to learn how to operate specific digital tools. Their skills in utilizing digital tools creatively are growing. In addition, the existence of extrinsic motivation that creates a competitive spirit among n1 students encourages them to hone their skills further using digital tools so as not to lag behind their classmates, as stated by the following students:

“.... my classmate made a good ppt, while I didn't know anything at that time, that's why I studied so that it was good too.... " [student AA].

“.... I like it when I try to make something new from ppt that my friend has never done before... " [student KJ].

"... made a ppt design that is interesting from others so that the value of my assignment is high. I also like it when my friends ask about how to make a good ppt..." [student IR].

On the internet cost per month variable, we found that there was no significant difference between students' digital literacy scores with quota/wifi fees US\$ 14 and students with quota/wifi fees < US\$ 14 . Access to the internet is very influential on a person's digital activities. With this access network, one can access any digital service they want. Based on research data it can be seen that having the cost to be able to access the internet is enough to make students have good digital literacy as long as they know and understand how to use and utilize digital resources intelligently, wisely, and effectively [14]. Regularly accessing the internet is not enough to improve a person's digital literacy. Digital literacy is not only able to access the internet but how individuals can utilize the results of their digital access to form a witty and wise mindset in using digital space effectively and efficiently and utilize the results of their access to transform digital information into valuable knowledge in life [15].

In addition to internet costs, another problem related to internet accessibility is the speed and stability of the network. In general, some rural areas in Indonesia have limitations in internet network access speed. During their study from home, some experienced network problems. Access speed and network stability is still a negative perception of students in distance learning. This condition can be expected to affect the development of students' digital literacy [16]. 
On the gender variable, the results showed no significant difference between the digital literacy scores of male and female students. The results of this study are in line with the previous study [17][18], showing that there is no significant difference between men and women. On the other hand, a survey [19] shows a digital divide between men and women due to more than half of women without formal education saying that they are not familiar or comfortable with the technology. However, this percentage drops to $15 \%$ in women with a minimum of secondary school education. Socio-cultural reasons play an essential role in explaining the digital gender gap. About a fifth of women believed that the Internet is not suitable for them for some cultural reasons in India and Egypt. As the World Wide Web Foundation (2019) points out, "the reasons for this digital gender gap are many - from economic and educational imbalances between men and women to cultural expectations and traditional gender roles, to policies that fail to address systematic inequalities"[20]. According to this perspective, the digital gender divide is linked to more significant structural inequalities that affect ICT infrastructure and how women use and utilize digital technologies [20][21].

\subsection{Correlation between digital literacy and learning outcomes}

The Pearson product-moment correlation coefficient was calculated to assess the relationship between digital literacy scores and student learning outcomes on digestive system materials. There is a weak positive correlation between the two variables, $r(61)=.309, p=.015$. The study results found that the higher the digital literacy score of the students, the more proficient the students were in finding and finding learning sites using digital applications such as Google, Youtube, and databases in the learning process. The use of this application in learning can help students broaden their horizons about the material of the digestive system and provide concrete visuals of the biological process through images and videos spread over the digital space. In addition, the higher the students' digital literacy, the more critical they are in assessing and evaluating the information about the digestive system material they get. The higher digital literacy score also shows the students' selfconfidence to participate in online discussion forums and discussion forums outside of class that discuss topics related to the digestive system. This finding is in line with the results of previous study [22][23], which show a positive correlation between learning outcomes and digital literacy interrelated. Other factors such as student learning independence can also affect the performance of student learning outcomes [24].

Digital literacy is the foundation that underpins the competent and purposeful use of digital technology by individuals in education. Having digital literacy requires more than just the technical ability; it also consists of various skills used in carrying out tasks in a digital environment [25]. So it makes sense if the position can affect the academic performance of students. 


\subsection{Limitations}

There are limited data on what students have access to while in the digital space, limiting the analysis of monthly internet costs and why the two cost groups are not significantly different. Therefore, further research is needed in this regard.

\section{Conclusion}

In general, the digital literacy of students in terms of all groupings is in the high category. An independent sample t-test conducted on the interest group found that the digital literacy of students who had an interest in digital technology was significantly higher than students who had no interest in digital technology. Independent sample ttest conducted on the internet cost group and gender resulted in the finding that there is no significant difference in digital literacy between students with quota/wifi fees US\$ 14/month and students with quota/wifi fees < US\$14/month. Likewise, based on gender, there was no significant difference in digital literacy between male and female students. However, a further examination found a significant difference between the digital literacy of male students and female students when viewed from the constructive element. There is a positive correlation between learning outcomes and digital literacy.

\section{$6 \quad$ References}

[1] Nikou, S., \& Aavakare, M. (2021). An assessment of the interplay between literacy and digital technology in higher education. Education and Information Technologies. https:// doi.org/10.1007/s10639-021-10451-0

[2] KOMINFO, P. (2021, 2). Literasi digital Jadi Kunci Keberhasilan Transformasi digital. Website Resmi Kementerian Komunikasi dan Informatika RI. https://www.kominfo.go.id/ content/detail/32823/literasi-digital-jadi-kunci-keberhasilan-transformasi-digital/0/berita_s $\underline{\text { atker }}$

[3] Brata, W. W., Wibowo, F. C., \& Rahmadina, N. (2021). Implementation of discovery learning in a digital class and its effect on student learning outcomes and learning independence level. F1000Research, 10, 386. https://doi.org/10.12688/f1000research.5176 $\underline{3.1}$

[4] KEMENDIKBUD. (2017). Gerakan Literasi Nasional. Gerakan Literasi Nasional. https://gln.kemdikbud.go.id/glnsite/wp-content/uploads/2017/10/literasi-DIGITAL.pdf

[5] UNESCO. (2018). A Global Framework of Reference on Digital Literacy Skills for Indicator 4.4.2 (51). UNESCO Institute for Statistics. https://uis.unesco.org/sites/default/fi les/documents/ip51-global-framework-reference-digital-literacy-skills-2018-en.pdf

[6] European Commission. (2019, January 9). The digital competence framework 2.0. EU Science Hub - European Commission. https://ec.europa.eu/jrc/en/digcomp/digital-compete nce-framework

[7] Belshaw, D. (2011). What is 'digital literacy'? : A pragmatic investigation [Doctoral dissertation]. https://clalliance.org/wp-content/uploads/files/doug-belshaw-edd-thesis-final. pdf 
[8] Belshaw, D. (2014). The Essential Elements of Digital Literacies. Self-published. http:// www.frysklab.nl/wp-content/uploads/2016/10/The-Essential-Elements-of-Digital-Literacie s-v1.0.pdf

[9] Brata, W. W. W., \& Arsila, P. (2021, March). The Effectiveness of Online Supported Learning in High School Students on Invertebrate Topics. In Journal of Physics: Conference Series (Vol. 1819, No. 1, p. 012048). IOP Publishing. https://doi.org/10.1088/ 1742-6596/1819/1/012048

[10] Harackiewicz, J. M., Smith, J. L., \& Priniski, S. J. (2016). Interest matters. Policy Insights from the Behavioral and Brain Sciences, 3(2), 220-227. https://doi.org/10.1177/237273221 $\underline{6655542}$

[11] Kolmykova, M., Gavrilovskaya, N., Barsukova, M., \& Kozlovskaya, D. (2021). Use of Microblogging, Social Networking, and Short Messages in E-learning for Information Culture Building. International Journal of Emerging Technologies in Learning, 16(14). https:// doi.org/10.3991/ijet.v16i14.22391

[12] Milenkova, V., Keranova, D., \& Peicheva, D. (2019). Digital skills and new media and information literacy in the conditions of digitization. Advances in Intelligent Systems and Computing, 65-72. https://doi.org/10.1007/978-3-030-20135-7_6

[13] Moreno-Morilla, C., Guzmán-Simón, F., \& García-Jiménez, E. (2021). Digital and information literacy inside and outside Spanish primary education schools. Learning, Culture and Social Interaction, 28, 100455. https://doi.org/10.1016/j.lcsi.2020.100455

[14] Burnett, C., \& Merchant, G. (2020). Undoing the digital: Sociomaterialism and literacy education. https://doi.org/10.4324/9781003023159

[15] Statti, A., \& Torres, K. M. (2020). Digital literacy: The need for technology integration and its impact on learning and engagement in community school environments. Peabody Journal of Education, 95(1), 90-100. https://doi.org/10.1080/0161956x.2019.1702426

[16] Rasmitadila, R., Widyasari, W., Humaira, M., Tambunan, A., Rachmadtullah, R. \& Samsudin, A. (2020). Using Blended Learning Approach (BLA) in Inclusive Education Course: A Study Investigating Teacher Students' Perception. International Journal of Emerging Technologies in Learning (iJET), 15(2), 72-85. https://doi.org/10.3991/ijet.v15i0 $\underline{2.9285}$

[17] Rodiah, S., \& Sopandi, W. (2021). Pengaruh Pembelajaran Online Terhadap Minat Belajar dan Literasi Digital Siswa Ditinjau dari Gender (Studi Komparatif Berbasis Gender Minat Belajar Siswa dan Literasi Digital pada Pembelajaran Jarak Jauh Akibat Pandemi Covid19 SD Pande. Konferensi Internasional Pendidikan Dasar. http://proceedings2.upi.edu/in dex.php/icee/article/view/1468

[18] Saha, S. R., \& Zaman, M. O. (2017). Gender digital divide in higher education: A study on University of Barisal, Bangladesh. IOSR Journal of Humanities and Social Science, 22(01), 11-17. https://doi.org/10.9790/0837-2201041117

[19] Intel, \& Dalberg. (2012). Women and the Web Bridging the Internet gap and creating new global opportunities in low and middle-income countries. Intel. https://www.intel.la/ content/dam/www/public/us/en/documents/pdf/women-and-the-web.pdf

[20] World Wide Web Foundation. (2019). Women's rights online digital gender gap audit scorecards. https://webfoundation.org/research/digital-gender-gap-audit/

[21] Mariscal, J., Mayne, G., Aneja, U., \& Sorgner, A. (2019). Bridging the gender digital gap. Economics, 13(1). https://doi.org/10.5018/economics-ejournal.ja.2019-9

[22] Lei, H., Xiong, Y., Chiu, M. M., Zhang, J., \& Cai, Z. (2021). The relationship between ICT literacy and academic achievement among students: A meta-analysis. Children and Youth Services Review, 127, 106123. https://doi.org/10.1016/j.childyouth.2021.106123 
[23] Yustika, G. P., \& Iswati, S. (2020). Digital literacy in formal online education: A short review. Dinamika Pendidikan, 15(1), 66-76. https://doi.org/10.15294/dp.v15i1.23779

[24] Brata WWW, Suriani C, Simatupang H, Siswanto, S, Panggabean, FTM: Prospective Science Teachers' Learning Independency Level on Blended Learning. In:Journal of Physics: Conference Series. 2020, February; Vol. 1462, No. 1, p. 012070. IOP Publishing. https://doi.org/10.1088/1742-6596/1462/1/012070

[25] Kolmykova, M., Gavrilovskaya, N., Barsukova, M., \& Kozlovskaya, D. (2021). Use of Microblogging, Social Networking, and Short Messages in E-learning for Information Culture Building. International Journal of Emerging Technologies in Learning, 16(14). https://doi.org/10.3991/ijet.v16i14.22391

\section{$7 \quad$ Authors}

Wasis Wuyung Wisnu Brata is a master and lecturer in Biology Education Department, Faculty of Mathematics and Natural Science, Universitas Negeri Medan, Indonesia. His research interest is learning strategies with the support of ICT's, LMS, digital literacy in learning; published more than 10 academic papers in recent years. With ORCID id: https://orcid.org/0000-0002-8895-8584.

Rahma Yanti Padang is a student in Biology Department, Faculty of Mathematics and Science, Universitas Negeri Medan, Indonesia. Her main interest of research is digital literacy (Email: rahmayantipadang @ gmail.com).

Eko Prasetya is a lecturer ini Biology Department, Faculty of Mathematics and Science, Universitas Negeri Medan, majoring in molecular biology. He also interested in information technology and data literacy. With ORCID id: https://orcid.org/00000002-8323-4413 (Email: ekoprasetya.biologi@gmail.com).

Cicik Suriani is a senior lecturer ini Biology Department, Faculty of Mathematics and Science, Universitas Negeri Medan, majoring in plant structure and development. Since becoming a lecturer, she also interested in researching about teaching and learning (Email: cicik.pendbio@gmail.com).

Nanda Pratiwi is a lecturer ini Biology Department, Faculty of Mathematics and Science, Universitas Negeri Medan. Her research interests include learning strategy, antibacterial activity. She has published widely in her area of research locally and internationally (Email: nanda.syamhari@gmail.com).

Article submitted 2021-09-27. Resubmitted 2021-11-09. Final acceptance 2021-11-09. Final version published as submitted by the authors. 